\title{
Gene silencing of IL-12 in dendritic cells inhibits autoimmune arthritis
}

\author{
Rong Li $i^{1,2}$, Xiufen Zheng ${ }^{2}$, Igor Popov ${ }^{2}$, Xusheng Zhang ${ }^{2}$, Hongmei Wang ${ }^{1}$, Motohiko Suzuki ${ }^{2}$, \\ Rosalia De Necochea-Campion ${ }^{3}$, Peter W French ${ }^{4}$, Di Chen ${ }^{2}$, Leo Siu ${ }^{2}$, David Koos ${ }^{5}$, Robert D Inman ${ }^{6}$ and \\ Wei-Ping Min $^{1,2,7^{*}}$
}

\begin{abstract}
Background: We have previously demonstrated that immune modulation can be accomplished by administration of gene silenced dendritic cells (DC) using siRNA. In this study, we demonstrate the therapeutic utilization of shRNA-modified DC as an antigen-specific tolerogenic vaccine strategy for autoimmune arthritis.

Methods: A shRNA that specifically targets IL-12 p35 was designed and cloned into a plasmid vectors (IL-12 shRNA). Bone marrow-derived DC from DBA/1 mice were transfected with the IL-12 shRNA construct in vitro. Mice with collagen II (CII)-induced arthritis (CIA) were treated with the modified DCs expressing the shRNA. Recall response and disease progression were assessed.

Results: After gene silencing of IL-12 in DC, DC were shown to selectively inhibit T cell proliferation on recall responses and in an MLR. In murine CIA, we demonstrated that administration of IL-12 shRNA-expressing DC that were pulsed with $\mathrm{Cll}$ inhibited progression of arthritis. The therapeutic effects were evidenced by decreased clinical scores, inhibition of inflammatory cell infiltration in the joint, and suppression of T cell and B cell responses to Cll.

Conclusion: We demonstrate a novel tolerance-inducing protocol for the treatment of autoimmune inflammatory joint disease in which the target antigen is known, utilizing DNA-directed RNA interference.
\end{abstract}

Keywords: shRNA, IL-12, Dendritic cells, Autoimmunity, Collagen-induced arthritis

\section{Background}

Rheumatoid Arthritis (RA) is a chronic autoimmune condition characterized by non-specific, usually symmetric inflammation of the peripheral joints, resulting in progressive destruction of articular and periarticular structures. One of the hallmark pathologies of RA is thickening and swelling of synovial tissue, primarily as a result of $\mathrm{T}$ cell production of inflammatory factors $[1,2]$. Up to $50 \%$ of the infiltrating leukocytes in the synovium are $\mathrm{T}$-lymphocytes, primarily $\mathrm{CD} 4^{+} \mathrm{T}$ cells with an activated/memory phenotype [3-5], expressing a Th1 bias [5,6]. Clinical treatment of RA involves initiating Disease Modifying Anti-Rheumatic Drug (DMARD) therapy early following diagnosis with subsequent optimization of drug therapy in order to have a greater beneficial

\footnotetext{
* Correspondence: weiping.min@uwo.ca

'Institute of Immunomodulation and Immunotherapy, Nanchang University Medical School, Nanchang, China

Full list of author information is available at the end of the article
}

impact on disease outcome [7]. DMARDs are antigennonspecific in their activities and include known immune suppressants such as methotrexate, leflunomide, hydroxychloroquine, sulfasalazine, and corticosteroids. The introduction of "biological DMARDs" such as Embrel and Remicade led to a major improvement in quality of life of RA patients, however these drugs are limited by cost, non-cure of the disease, and adverse effects such as heightened risk of infection $[8,9]$.

Despite promising animal data, to date, antigen-specific treatments of RA have not been clinically successful. While approaches such as intravenous immunoglobulin [10], oral tolerance [11,12], and tolerogenic peptide therapy [13] have demonstrated promising results in various models, clinical trials have yielded results that are mediocre at best. Dendritic cell (DC) therapy is considered one of the most potent means of antigen-specifically modulating an immune response given the innate propensity of DC to either activate or inhibit adaptive 
immune responses [14-17]. The recent FDA approval of Provenge as an antigen-specific immunotherapy for prostate cancer attests to the ability of this approach to be translated clinically [18]. Although exceptions exist, generally speaking, in immature states, DC act primarily as tolerogenic cells, caused deviation of Th1 immunity, as well as generation of $\mathrm{T}$ regulatory cells $[19,20]$, whereas mature DC are immune stimulatory. We have previously applied these findings in the animal model of RA, collagen induced arthritis (CIA) to demonstrate that DC made immature by treatment with a synthetic RelB inhibitor prevented disease progression [21]. These findings were confirmed in subsequent studies in which we generated "artificially immature" DC using siRNA to silence the markers of maturation, CD40, CD80, and CD86. When these DC were pulsed with collagen II, the autoantigen implicated in CIA, we observed regression of disease [22,23]. Given that $\mathrm{T}$ cell activation involves not only cell surface costimulatory molecules but also cytokines, we chose to examine whether silencing of the cytokine IL-12 on DC would also induce a pro-tolerogenic activity.

The cytokine IL-12 is a soluble factor used by the DC to guide differentiation of naïve $\mathrm{T}$ cells into a Th1, cytotoxic/inflammatory state [24-26]. Several studies suggest that IL-12 is associated with autoimmunity in a pathologies such as arthritis [27,28], diabetes [29,30], multiple sclerosis [31,32], and thyroiditis [33,34]. Therefore, a method of selectively inhibiting the IL-12 production at the level of the DC may be an ideal mechanism of immunotherapy for autoimmune diseases. Supporting the importance of IL-12 in DC mediated immune modulation, we have previously demonstrated that siRNAmediated silencing of the IL-12p35 gene on DC causes immune deviation on recall response towards a Th2-like profile [35]. In the current study we silenced the IL12 p35 gene on DC that were pulsed with collagen II protein. We demonstrated that administration of this antigen specific "tolerogenic vaccine" was capable of inducing a Th2-biased recall response, as well as suppression of pathology in the CIA model. These findings may be supportive of future clinical development using IL-12p35 silenced antigen-pulsed DC.

\section{Methods \\ Animals}

Male DBA/1 LacJ and BALB/c mice (The Jackson Laboratories, Bar Harbor, ME), 5 weeks of age, were kept in filter-top cages in the Animal Care and Veterinary Services Facility at the University of Western Ontario according to the Canadian Council for Animal Care Guidelines. Mice were fed by food and water and allowed to settle for 2 weeks before initiation of experiments, which had ethical approval from the university review board.

\section{CIA model}

DBA/1 LacJ mice, 7 weeks of age, were intradermally immunized (Day 0) at several sites into the base of the tail with $200 \mu \mathrm{g}$ of bovine type II collagen (CII) (SigmaAldrich, St. Louis, MO) dissolved in $100 \mu \mathrm{l}$ of $0.05 \mathrm{M}$ acetic acid and mixed with an equal volume of complete Freund's adjuvant (CFA) (Sigma). CII was dissolved at a concentration of $2 \mathrm{mg} / \mathrm{ml}$ by stirring overnight at $4^{\circ} \mathrm{C}$. On day 21 after priming, the mice received an intraperitoneal booster injection with $200 \mu \mathrm{g}$ of CII in the equal volume $(100 \mu \mathrm{l})$ of PBS. Mice were examined visually three times per week for the appearance of arthritis in the peripheral joints, and arthritis score index for disease severity was given as follows: 0 - no evidence of erythema and swelling; 1 - erythema and mild swelling confined to the mid-foot (tarsals) or ankle joint; 2 erythema and mild swelling extending from the ankle to the mid-foot; 3 - erythema and moderate swelling extending from the ankle to the metatarsal joints; 4 erythema and severe swelling encompass the ankle, foot, and digits. Scoring was done by two independent observers, without knowledge of the experimental and control groups.

\section{DC cultures}

At Day 0, bone marrow cells were flushed from the femurs and tibias of DBA/1 LacJ mice, washed and cultured in 6-well plates (Corning, NY) at $4 \times 10^{6}$ cells/ well in $4 \mathrm{ml}$ of complete medium (RPMI 1640 supplemented with $2 \mathrm{mM}$ L-glutamine, $100 \mathrm{U} / \mathrm{ml}$ penicillin, $100 \mu \mathrm{g}$ of streptomycin, $50 \mu \mathrm{M} 2-\mathrm{ME}$, and 10\% FCS (all from Life Technologies, Ontario, Canada) supplemented with recombinant GM-CSF (10 ng/ml; PeproTech, Rocky Hill, NJ) and recombinant mouse IL-4 (10 ng/ml; PeproTech). All cultures were incubated at $37^{\circ} \mathrm{C}$ in $5 \%$ humidified $\mathrm{CO}_{2}$. Non-adherent cells were removed after $48 \mathrm{~h}$ of culture (Day 2) and fresh medium was added every $48 \mathrm{~h}$.

\section{shRNA expressing vectors and transfection}

siRNA sequences were selected according to the method of Elbashir SM et al. [36]. The siRNA sequence specific for IL-12p35 (AACCUGCUGAAGACCACAGAU) was selected and cloned into Psilencer 3.1 vector (Ambion, Austin, TX) which expresses short hairpin RNA (shRNA) under the control of the mouse U6 promoter, using the method described by the supplier of the vector. IL-12 shRNA was sequenced and prepared in a large scale for in vitro and in vivo study. Gene silencing was examined with DC. DC were generated from bone marrow progenitor cells as previously described [35]. Transfection of DC was conducted as described previously [36]. 24 h before transfection (day 4), DC were plated to be $60-90 \%$ confluent on the day of 
transfection. On day 5, $2 \mu \mathrm{g}$ of IL-12 shRNA and $3 \mu \mathrm{l}$ of GenePORTER reagent (Gene Therapy Systems, San Diego, CA) were separately diluted with serum-free medium RPMI 1640 using 1/2 of the transfection volume $(125 \mu \mathrm{l})$. The diluted DNA was added to the diluted GenePORTER reagent, mixed rapidly and incubated in total volume of $250 \mu \mathrm{l}$ of the medium at room temperature for $45 \mathrm{~min}$. The culture medium from the DC was aspirated, and the DNA-GenePORTER mixture was added carefully to the DC. Mock controls were transfected with $3 \mu$ l of the GenePORTER reagent alone. After 4-h incubation, an equal volume of RPMI $1640(250 \mu \mathrm{l})$ supplemented with $20 \%$ FCS was added to the cells. $48 \mathrm{~h}$ after the start of transfection (day 7), DC were washed and pulsed with $10 \mu \mathrm{g} / \mathrm{ml}$ of CII for $24 \mathrm{~h}$. At day 8, DC were then activated with LPS/TNF- $\alpha$ for additional 24 h. 7 days before and/or 12 days after priming with CII, different groups of mice with 6 animals per group were i.p. injected with shRNA-transfected or control DC at a dose of $5 \times 10^{6}$ cells per mouse.

\section{RT-PCR}

Total RNA was extracted from cells using Trizol (Invitrogen). $3 \mu \mathrm{g}$ total RNA was used to synthesize the cDNA with oligdT and reverse transcriptase (Invitrogen) in $20 \mu \mathrm{l}$ reaction volume. Primers used for the amplification of murine IL-12, IFN $\gamma$, IL-2, IL-4, IL-10 and GAPDH were as follows [37]: IL-12, 5'- CTT GCC CTC CTA AAC CAC CTC AGT-3' (forward) and 5' - CCA CCA GCA TGC CCT TGT CTA-3' (reverse); IFN $\gamma, 5^{\prime}$ CAC GGC ACA GTC ATT GAA AGC CTA-3' (forward) and 5' - TGA GGC TGG ATT CCG GCA ACA GCT-3' (reverse);

IL-2, 5' - ACA TTG ACA CTT GTG CTC CGT GTC3' (forward) and 5'- TTG AGG GCT TGT TGA GAT GAT GCT-3' (reverse); IL-4, 5'- AGC TAG TTG TCA TCC TGC TCT TCT-3' (forward) and 5'- CGA GTA ATC CAT TTG CAT GAT GCT-3' (reverse); IL-10, 5'GAA GAC AAT AAC TGC ACC CAC TTC-3' (forward) and 5' - ATG GCC TTG TAG ACA CCT TGG TCT-3' (reverse); GAPDH, 5'-TGA TGA CAT CAA GAA GGT GGT GAA-3' (forward) and 5'-TGG GAT GGA AAT TGT GAG GGA GAT-3' (reverse).

Polymerase chain reaction (PCR) was performed in a $25 \mu \mathrm{l}$ of reaction volume containing $0.2 \mu \mathrm{mol} / \mathrm{L}$ primers, $1 \mathrm{U}$ Taq DNA polymerase under the following conditions: $95^{\circ} \mathrm{C}$ for $30 \mathrm{~s}, 58^{\circ} \mathrm{C}$ for $30 \mathrm{~s}$, and then $72^{\circ} \mathrm{C}$ for 30 $\mathrm{s}$ (30 cycles). PCR products were visualized with ethidium bromide on $1.5 \%$ agarose gel.

\section{Mixed leukocyte reaction (MLR)}

At day 5 of culture, bone marrow-derived DC from DBA/1 LacJ mice were transfected with IL-12 and scrambled siRNAs or mock-transfected followed by activation with LPS/TNF- $\alpha$. Activated DC were irradiated (3,000 rad) and seeded in triplicate in a flat-bottom 96-well plate (Corning) for use as stimulator cells. Spleen $\mathrm{T}$ cells from BALB/c mice were isolated by gradient centrifugation over Ficoll-Paque (Amersham Pharmacia Biotech, Quebec) and added as responders $(5 \times$ $10^{5}$ cells/well). The mixed lymphocytes were cultured at $37^{\circ} \mathrm{C}$ for $72 \mathrm{~h}$ in $200 \mu \mathrm{l}$ of RPMI 1640 supplemented with $10 \%$ FCS, $100 \mathrm{U} / \mathrm{ml}$ of penicillin, and $100 \mu \mathrm{g} / \mathrm{ml}$ of streptomycin and pulsed with $1 \mu \mathrm{Ci} /$ well of ${ }^{3} \mathrm{H}$-labelled thymidine (Amersham Pharmacia Biotech) for the last $16 \mathrm{~h}$ of culture. Finally, cells were harvested onto glass fiber filters, and the radioactivity incorporated was quantitated using a Wallac Betaplate liquid scintillation counter (Beckman, Fullerton, CA). Results were expressed as the mean counts per min of triplicate cultures \pm SEM.

\section{Proliferation assays}

$\mathrm{T}$ cell proliferative responses to $\mathrm{CII}$ in subsequent groups of mice were measured with a standard microtiter assay. Following CII immunization, the proliferative responses could be detected for several weeks. Immune cells from either draining lymph node or spleen $\mathrm{T}$ cells collected from the mice treated with CII and IL-12 silenced DC or control DC, at $5 \times 10^{5}$ /well were seeded to a 96 -well flatbottom microtiter plate (Corning) in triplicates and mixed with serial dilutions of CII with concentrations ranging from 5 to $50 \mu \mathrm{g} /$ well. Following a $72 \mathrm{~h}$ incubation, $1 \mu \mathrm{Ci}$ of $\left[{ }^{3} \mathrm{H}\right]$ thymidine (Amersham) was added to each well for $16 \mathrm{~h}$. Using an automated cell harvester, the cells were collected onto glass microfiber filter, and the radioactive labeling incorporation was measured by a Wallac Betaplate liquid scintillation counter.

\section{Anti-Cll antibody measurement}

CII-specific Abs were evaluated using a standard indirect ELISA in which $500 \mathrm{ng}$ of CII was absorbed to each well of a 96-well microtitre plate. Following blocking and washing steps, serial dilutions of immune mouse serum were added to the appropriate wells in duplicates and incubated overnight at $4^{\circ} \mathrm{C}$. Dilutions of serum were 1:100-1:100,000. To develop the ELISA, horseradish peroxidase-conjugated goat anti-mouse IgG Fc and orthophenylenediamine dihydrochloride substrate buffer (Sigma) were used. The OD of each well was measured at a wavelength of $490 \mathrm{~nm}$ in an ELISA plate reader.

\section{Cytokine quantification}

Mock or shRNA-transfected DC of DBA/1 LacJ origin were cultured with the allogeneic $(\mathrm{BALB} / \mathrm{c}) \mathrm{T}$ cells or alone for $48 \mathrm{~h}$. The supernatants were collected and assessed for DC cytokines (IL-10 and IL-12) and T cell cytokines (IFN- $\gamma$ and IL-4) by ELISA. Cytokine-specific 
ELISA (Endogen, Rockford, IL) was used for detecting cytokine concentrations in culture supernatants according to the manufacturer's instructions using a Benchmark Microplate Reader (Bio-Rad, Hercules, CA).

\section{Histology}

Paws from experimental and control groups of freshly dissected mice were removed and joint tissues were immersion-fixed for 4 day in $10 \%$ (wt/vol) neutral buffered formalin in 0.15 M PBS (pH 7.4). After decalcification by immersing in Decalcifier I solution (Winnipeg, Canada) overnight and subsequent dehydration in a gradient of alcohols, tissues were rinsed in running water. The specimens were processed for paraffin embedding in paraplast (BDH, Dorset, UK) as routine procedure. Serial paraffin sections throughout the joint were cut at $5-\mu \mathrm{m}$ thickness on a microtome, heated at $60^{\circ} \mathrm{C}$ for 30 min, and deparaffinized. Hydration was done by transferring the sections through the following solutions: triple to xylene for $6 \mathrm{~min}$, and then for $2 \mathrm{~min}$ to $100 \%$ ethanol twice, 95\% ethanol, and 70\% ethanol. Sections were stained with $H \& E$ and mounted on glass slides.

\section{Intracellular cytokine staining and flow cytometry}

Transfected DCs were treated with $20 \mathrm{ng} / \mathrm{ml}$ phorbol myristate acetate and stained with FITC-conjugated IL12. Ig of the same isotype was used as controls. Flow cytometry analysis was performed in a FACScan II (Becton Dickinson, San Jose, CA- BD) system using FACSDiva software (BD).

\section{Statistical analysis}

Data are expressed as mean \pm SEM. Differences between different groups of mice were compared using the Mann-Whitney $U$ test for nonparametric data. A $P$ value less than 0.05 was considered significant.

\section{Results}

\section{Silencing DC with IL-12 shRNA}

Silencing of IL-12p35 on bone marrow derived DC was previously performed by our group using presynthesized siRNA [35]. Although this approach is widely used, one disadvantage is the relatively low efficacy due to consumption of the exogenously administered siRNA. An alternative approach would be to induce the cell to produce siRNA endogenously. One way of achieving this is using so-called DNA-directed RNAi (ddRNAi), which utilizes a DNA construct expressing double stranded RNA. Accordingly we transfected DC with a vector comprising a hairpin loop of siRNA (shRNA), driven by U6 promoter.

We determined the gene silencing efficacy of IL-12 shRNA on DC by RT-PCR (Figure 1A). IL-12 shRNA reduced IL-12 expression on DC by 3 -fold as compared with control. The gene silencing effect of IL-12 shRNA

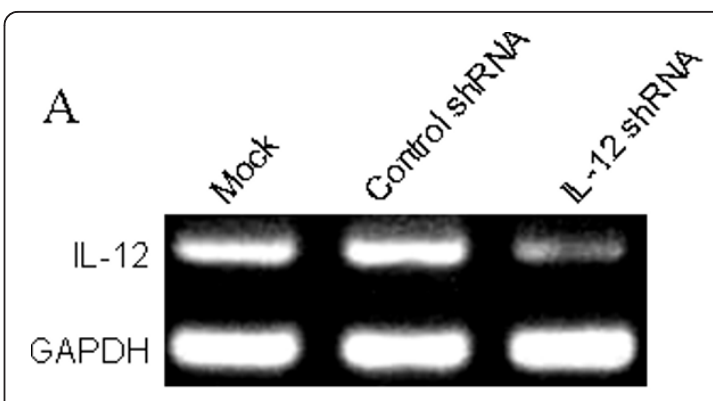

B

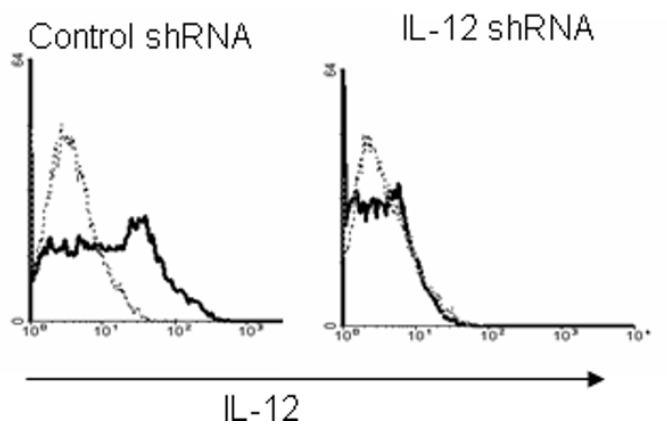

Figure 1 Gene silencing of IL-12 shRNA on DC. (A) Gene silencing efficacy of IL-12 shRNA was determined by RT-PCR. DC were cultured for 4 days as described in the methods. On day 5, $10^{6}$ DC were transfected with $2 \mu \mathrm{g}$ of IL-12 shRNA using GenePORTER reagent. One day after transfection, DC were harvested and mRNA detected. (B) Gene silencing efficacy of IL-12 shRNA was determined by flow cytometry. DC were transfected as above and collected $48 \mathrm{~h}$ after transfection. DC were intracellular stained with FITC labeled anti-IL-12 antibody and followed by flow cytometry analysis. The data presented one of three independent experiments.

was further confirmed at the protein level by intracellular staining with anti-IL-12 antibody using flow cytometry (Figure 1B). These data suggest feasibility of specific gene silencing in DC using the shRNA approach.

\section{In vitro immune modulation by IL-12 shRNA}

IL-12 is an important cytokine for the interaction of DC and T cells. IL- 12 secreted by DC controls T helper cell deviation. Thus, we assessed whether silencing of IL12 p35 using shRNA would alter the ability of the DC to modulate a Th1 to Th2 shift. Using an allogeneic system, we co-cultured C57/BL6 DC, treated with IL-12 shRNA, together with responder BALB/c T cells. This resulted in a predominant Th2 cytokine profile (e.g. high IL-4, low IFN- $\gamma$ ), as compared to the co-culture with DC treated with control shRNA which possessed a Th1 profile (Figure $2 \mathrm{~A})$. We next tested the antigen presentation capacity of DC after gene silencing of IL- 12 by quantifying proliferative response of the $\mathrm{BALB} / \mathrm{C} \mathrm{T}$ cells reacting against control and IL-12 silenced C57BL/6 DC. Figure 2B showed 


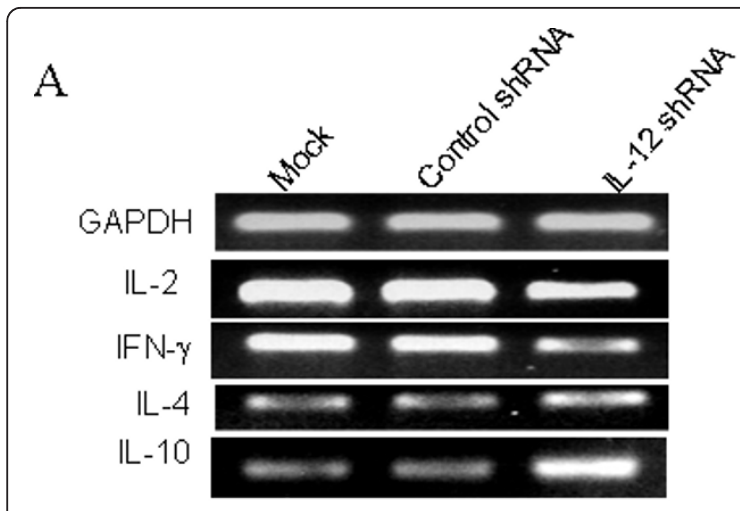

B

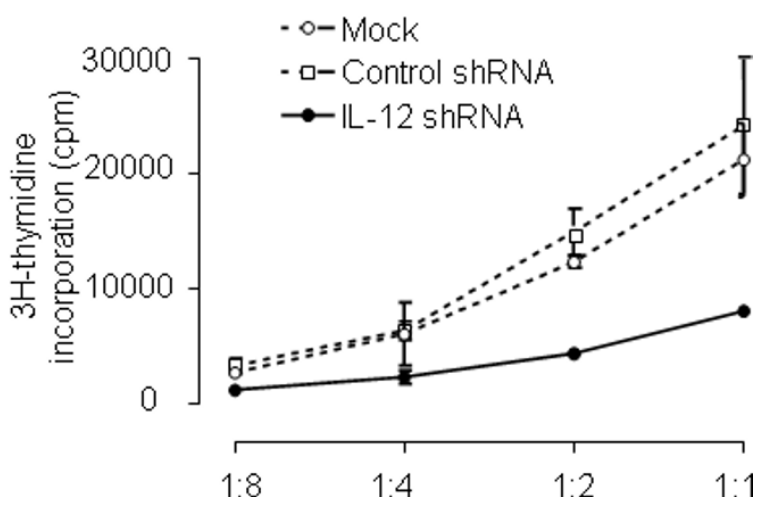

Figure 2 Immune modulation by IL-12 shRNA silenced DC. $(\boldsymbol{A})$ IL-12 silenced DC promote Th2 cytokine production. Control and siRNA-treated DC were cultured with allogeneic T cells for 3 days. Co-cultured $T$ cells were harvested and gene expression of IFN $\gamma$, IL2, IL-4 and IL-10 were detected by RT-PCR. (B) DC silenced with IL12 shRNA inhibited allogeneic T cell proliferation. DC $\left(1 \times 10^{5}\right.$ cells $/$ well) were co-cultured with allo-T cells $\left(5 \times 10^{5}\right.$ cells/well) in 96-well plate for $72 \mathrm{~h} .1 \mu \mathrm{Ci} /$ well of ${ }^{3} \mathrm{H}$-labelled thymidine was added to the culture for the last $16 \mathrm{~h}$ of culture and proliferation was assessed by scintillation counting. Results were expressed as the mean counts per min of triplicate cultures \pm SEM. ${ }^{*}=P<0.05$.

that $\mathrm{T}$ cell response was reduced after being stimulated by the DC in which IL-12 gene is silenced. These data suggest that IL-12 not only plays a role in production of IFN-g and IL-4, but also is involved in stimulation of $\mathrm{T}$ cell proliferation by allogeneic DC. Accordingly, we sought to determine whether DC modulated in this manner may be useful for modulating an immune response in vivo in an autoimmune disease model.

Inhibition of CIA by treatment with IL-12 shRNAtransfected DC

The CIA model of RA is an ideal system for assessment of therapeutics based on the fact that it displays similar onset, progression, and pathology to clinical RA. Importantly, the autoantigen in CIA is molecularly defined CII and $\mathrm{T}$ cell responses to this protein are essential for disease continuation [38]. We have previously demonstrated that silencing expression of IL-12p35 in DC leads to in vivo immune modulation of $\mathrm{T}$ cell response to a nominal antigen KLH [35]. In the previous study we utilized presynthesized siRNA, and we did not assess ability to inhibit immunity in a therapeutic model. In this study, we used a clinically relevant model of autoimmune arthritis and evaluated two treatment protocols. When, 12 days after priming with CII, DBA/1 mice were administered a single injection of IL-12 shRNA-transfected DC pulsed with CII, an inhibition of arthritis clinical score had been observed 11 days after arthritis onset as opposed to control-treated mice receiving DC that were not gene-silenced for IL-12 (Figure 3A). The average clinical scores per affected paw in the control group were two times higher than that in the treatment group. To confirm the therapeutic effects by IL-12 silenced DC, we further sought to examine microscopic histological differences induced by treatment of CIA mice with the IL-12-silenced and CII-pulsed DC. Accordingly, animals treated with IL-12 shRNA-transfected DC or control DC were sacrificed 4 weeks following onset of arthritis and joints were examined by serial sectioning. We observed that control mice possessed severe bone erosion, pannus formation, and synovitis (Figure 3B). A marked neutrophilic and mononuclear cell infiltration was seen. In contrast, joint histology of the IL-12-silenced DC treated mice revealed markedly attenuated morphological changes and cellular infiltration, and the preservation of normal cartilage structure (Figure 3C). The histological verification of the arthritis clinical score strongly suggests that the IL-12 silenced and CII-pulsed DCs can serve as a potent tolerogenic vaccine that might be useful for the treatment of autoimmune arthritis.

While the protocol above was therapeutic in the sense that the intervention was given after initiation of immune response, we chose to determine whether the combination of a prophylactic (i.e. 7 days before priming with $\mathrm{CII}$ ) and the therapeutic IL-12-silenced DC injection resulted in additive or synergistic inhibition of arthritis development. Using this combination we observed a lower severity of arthritis, as compared to a single injection protocol (Figure 3D). Furthermore, the control DC group had higher average clinical score than experimental group ranged from 2fold to more than 4-fold depending on the timepoint of assessment. This suggests that a combination of cellular vaccine strategies could lead to additive anti-arthritis effects.

\section{IL-12 shRNA silenced DC inhibited CII-specific T cell response in arthritic mice}

It has been previously described that immune modulation by administration of IL-10-treated DC can inhibit 


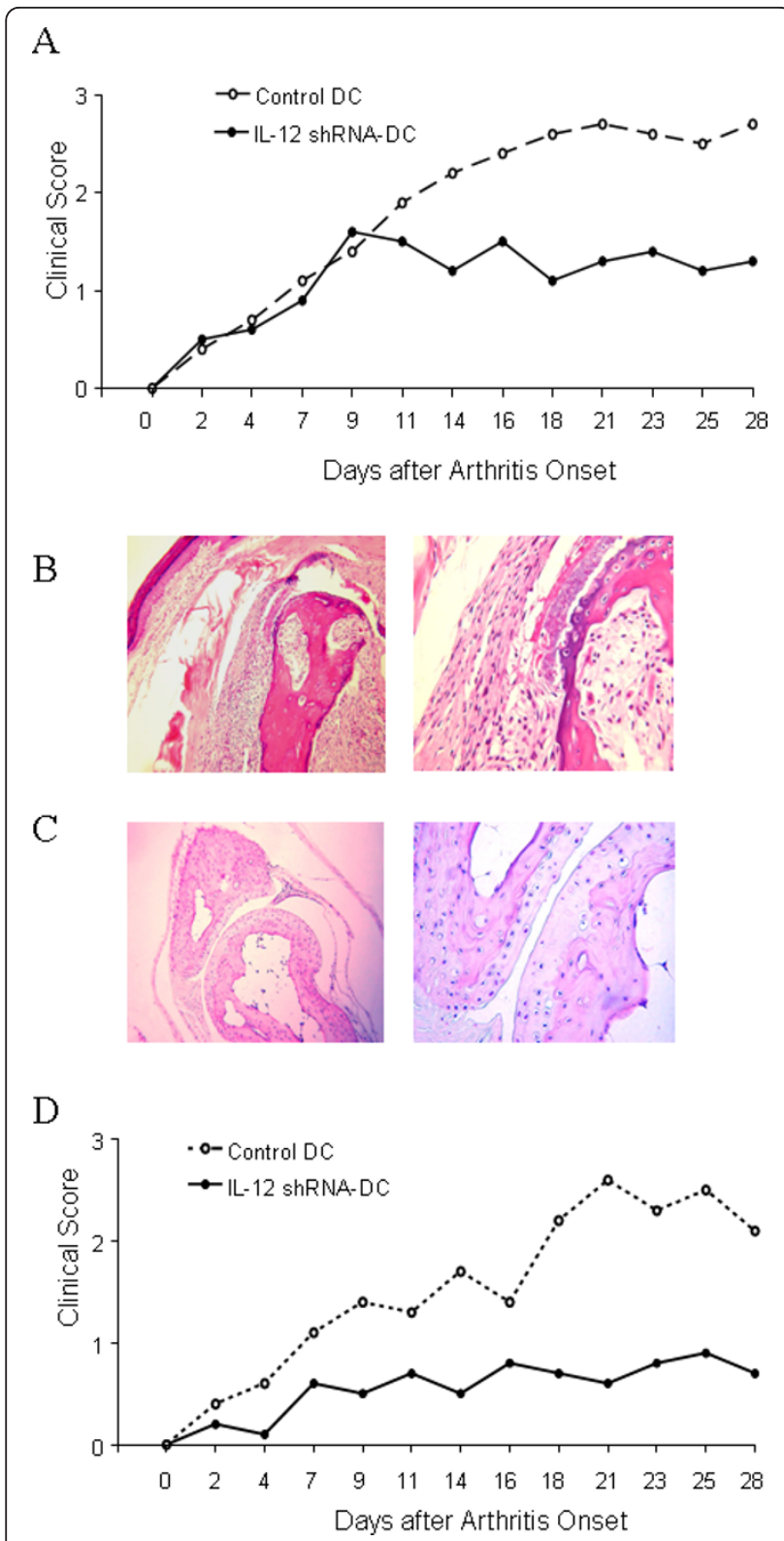

Figure 3 Inhibition of clinical development of $\mathrm{CIA}$ in mice injected with IL-12 shRNA-transfected DC. $(\boldsymbol{A})$ Index of disease severity of joint after single DC treatment. 12 days after intradermal challenge with CII (200 $\mathrm{mg}$ per mouse), DBA/1 LacJ mice were treated with one i.p. injections of $5 \times 10^{6} \mathrm{IL}-12$-silenced $\mathrm{DC}$ pulsed with Cll $(10 \mu \mathrm{g} / \mathrm{ml})$. Control siRNA -transfected DC pulsed with CII served as a control. All mice were i.p. boosted with the same dose of CII 21 day after priming with the antigen. The animals were observed for 4 weeks since arthritis onset. Each limb was graded on a scale from 0 to 4 and the average clinical score per affected paw was calculated. Each point denotes the score of 5 mice in each group. Results represent 1 of 3 experiments. ${ }^{*}=P<0.05$ versus control DC. (B) Histological sections of joints from arthritis mice injected with control DC. H\&E stained sagittal sections of proximal interphalangeal joints. Sections from control mice show widespread inflammation cell infiltration, mild edema and congestion. Cartilage surface became uneven due to soft bone damage. (C) Histological sections of joints from arthritis mice injected with IL-12 shRNA- transfected DC. The majority of sections from animals treated with single injection of IL-12-silenced DC pulsed with CII do not show monocyte infiltration, edema and congestion. Cartilage surface appears smooth. Original magnification $\times 100$. Results represent 1 of 15 mice. (D) Index of disease severity of joint after two DC treatments. 7 days before and 12 days after intradermal challenge with Cll (200 $\mu \mathrm{g}$ per mouse), DBA/1 LacJ mice were treated with i.p. injections of $5 \times 10^{6} \mathrm{IL}-12$-silenced DC pulsed with CII $(10 \mu \mathrm{g} / \mathrm{ml})$. Mock-transfected DC pulsed with CII served as a control. All mice were i.p. boosted with the same dose of Cll 21 day after priming with the antigen. The animals were observed for 4 weeks since arthritis onset. Each limb was graded on a scale from 0 to 4 and the average clinical score per affected paw was calculated. Each point denotes the score of 5 mice in each group. Results represent 1 of 3 experiments. ${ }^{*}=P<0.05$ versus control DC.

antigen-specific recall response [39]. However, the long-term effects of immune modulation with inhibitory DC have not been reported. Here, we have measured CII-specific $\mathrm{T}$ cell recall responses after arthritis development in mice treated with IL-12 shRNA-transfected DC pulsed with CII. Four-weeks after arthritis onset, we extracted lymph node and spleen $\mathrm{T}$ cells from correspondent group of animals in 4 weeks following the first signs of arthritis. A profound suppression of response to CII was observed in $\mathrm{T}$ cells derived from both lymph node (Figure 4A) and spleen (Figure 4B) sources in the mice treated with IL-12 siRNA.

\section{Reduced threshold for inhibition of antibody response to CII in arthritis mice}

The importance of CII-specific antibodies in development of CIA pathology is well-known [21]. However, control of antibody responses by DC has not been previously examined in a therapeutic sense. Tolerogenic DC may directly block antibody production through inhibition of BlyS and APRIL, factors which the DC use to directly induce Ig production and class switching in $\mathrm{B}$ cells $[40,41]$. Alternatively, tolerogenic DC may indirectly prevent antibody production through the inhibition of $\mathrm{T}$ cell helper function. Here, we assessed antibody responses to CII in animals 4 weeks after arthritis onset. Using a titration experiment, we compared the serum levels of anti-CII Ig from control mice with CIA mice treated with single injection of IL-12-silenced/CII-pulsed DC twice, before and after CII administration. CII-specific antibody response was inhibited by both the single injection (Figure 5A) and by the two injections of the IL-12 silenced DC (Figure 5B). This indicates that the IL-12 shRNA-transfected DC represent an immunomodulatory therapeutic strategy since they are not only involved in suppression of $\mathrm{T}$ cell responses but also in antibody production. 


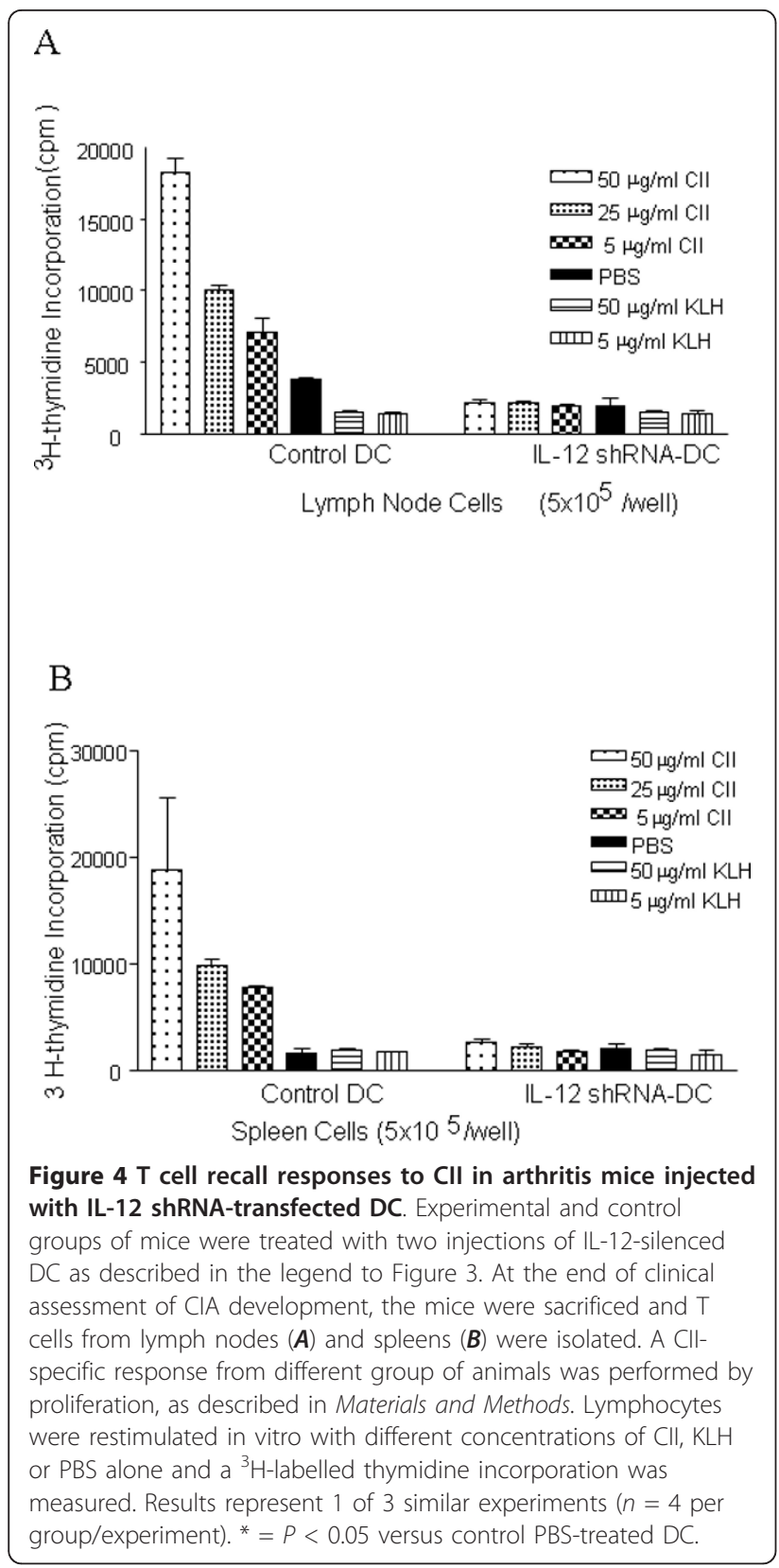

\section{Discussion}

We previously demonstrated that silencing IL-12 resulted in immune deviation and modulation in vitro and in vivo [21]. However, to date, therapeutic utilization of shRNAtransfected DC has not been performed in arthritis. In this study, we have reported that silencing the Th1-inducing cytokine IL-12 with DNA-directed RNA interference (ddRNAi) in the form of shRNA leads to a potent Th2 deviation that culminates in inhibition of CIA, the murine model of rheumatoid arthritis. This model is optimal for antigen-specific immune modulation since: 1) disease is associated with a defined antigen, CII [42]; 2) a defined

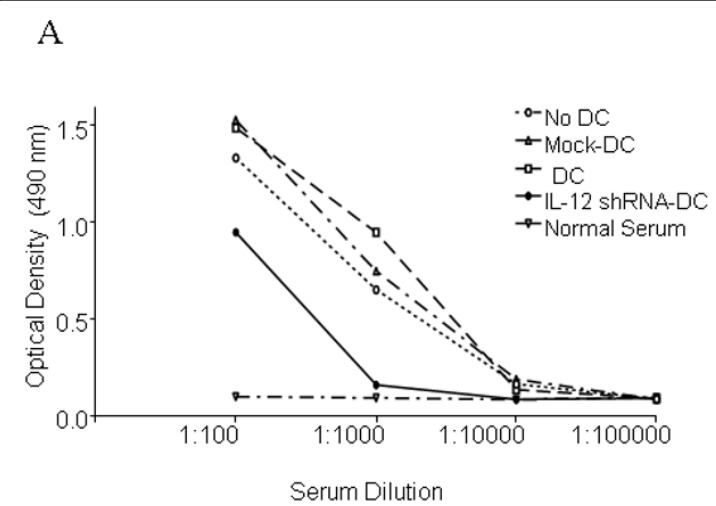

B

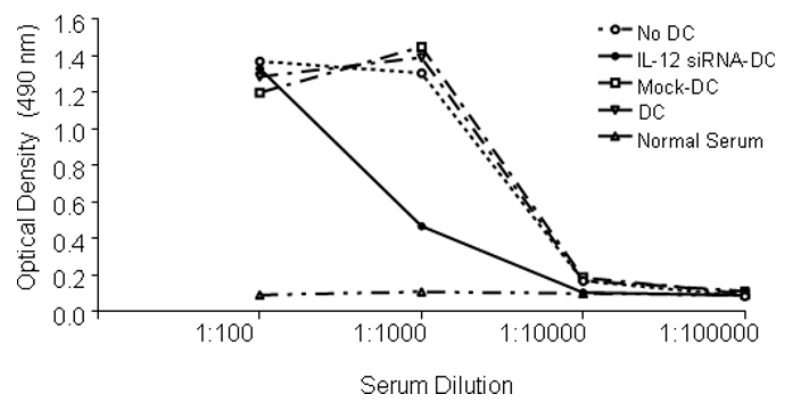

Figure 5 Inhibition of Cll-specific antibody production in arthritis mice following injections with IL-12 shRNA-transfected DC. Blood was taken 4 weeks after arthritis onset from experimental and control groups of mice treated with one $(\boldsymbol{A})$ or two $(\boldsymbol{B})$ injections of IL-12-silenced DC, as described in the legend to the Figure 2. Serum levels of anti-CII immunoglobulin Fc were determined using ELISA. Results show average levels of antibodies expressed as OD ( $n=4$ per group/experiment). ${ }^{*}=P<0.05$ versus control shRNA-transfected DC.

cytokine response, which is known to be IL-12-dependent, leading to IFN- $\gamma$-driven activation of macrophages and synoviocytes, and is causative in the inflammatory lesions that appear [40]; and 3) the CIA model is modifiable by exogenous manipulations [43]. Our experimental protocols consisted of administering CII-pulsed IL-12silenced DC at day -7 , and/or day 12 following the first CII challenge. These protocols were used to assess both prophylactic and therapeutic effects of the tolerogenic IL-12 shRNA-transfected DC.

Mature myeloid DC possess high expression of MHC class II molecules (signal 1), costimulatory molecules (signal 2) and IL-12 (signal 3). Signals 1 and 2 stimulate $\mathrm{T}$ cell activation, while signal 3 polarizes $\mathrm{T}$-helper ( $\mathrm{Th}$ ) differentiation. Therefore, immune modulation can be achieved through inhibition of immune molecules in DC by various blockades such as antibodies [44], fusion proteins $[45,46]$ or antisense oligonucleotides [47], and pharmacological agents [21]. In comparison with these previously used blocking methods, silencing gene 
expression through ddRNAi may prove superior to conventional gene or antibody blocking approaches for the following reasons: 1) blocking efficacy is potent [48]; 2) targeting gene expression is specific to one nucleotide mismatch [49]; 3) inhibitory effects can be passed for multiple generations to daughter cells [50]; 4) in vitro transfection efficacy is high [35] and can be expressed in a stable manner [51]; 5) in vivo use may be more practical and safer than antibody approaches due to lower concentrations needed for silencing, and lack of neutralizing antibody production; 6) tissue or cell specific gene targeting is possible using specific promoter vectors $[52,53]$ or specific antibody conjugated liposomes $[27,54]$; 7) simultaneously targeting multiple genes or multiple exons silencing is possible for increasing efficacy [55]. Clinical efficacy of ddRNAi has been recently demonstrated in AIDS-related lymphoma patients who received viral-vector transfected autologous CD34 cells, in which it was demonstrated that the cells and their progeny expressed the shRNA for at least two years from a single ex vivo transfection treatment [56].

In contrast to other methods of DC modulation, induction of RNAi in this cell population offers an approach to specifically modify the immune-regulating abilities of DC. In our first description of shRNAmanipulated DC, we demonstrated that silencing of IL12 p35 is sufficient to induce a DC population that stimulates Th2 immune responses in vitro and in vivo [35]. Since DC can be pulsed with antigenic peptides or mRNA ex vivo, the shRNA-modification of this cell type offers the ability to generate vaccines not only for stimulation but also for inhibition of immunity. Subsequent to our initial study, two other groups have reported utilization of RNAi in DC. Laderach et al [57] reported specific and efficient silencing the NF- $\kappa \mathrm{B}$ gene in human monocyte-derived DC using siRNA transfected via electroporation. This study was particularly interesting since it clearly demonstrated the ability of siRNA to study the specific functions of subunits comprising multimeric transcription factors [57]. Silencing of DC cell lines using shRNA was used by Wong et al to silence the Plexin A1 gene, demonstrating that this neuronal-specific protein is critical in DC-T cell interactions [58]. More recently, we induced transplant tolerance through gene silencing of RelB [59]. These reports indicate the utility of RNAi for immunological and molecular investigations of DC. Despite the success of silencing DC by siRNA, several key issues of gene silencing in DC remains undetermined, such as siRNA delivery methods, persistence of silencing efficacy, and multiple gene silencing. We demonstrate that RNA interference can be accomplished in DC either by transient delivery of presynthesized siRNA or by transfection of plasmid encoding shRNA. Utilizing shRNA, the gene silencing efficacy can last at least up to the end point of DC culture [60].

\section{Conclusion}

These results serve as a proof-of-principle study, illustrating that DNA-directed RNA interference in the form of shRNA can be used efficiently, and rapidly for production of tailor-made tolerogenic DC that are primed with specific antigen for a cellular "tolerogenic vaccine". With the identification of a plethora of novel immune stimulatory genes, it raises the possibility of using ddRNAi gene-silenced tolerogenic DC for individualized therapy of autoimmune diseases.

\section{Abbreviations}

siRNA: Small interfering RNA; shRNA: Short hairpin RNA; ddRNAi: DNA directed RNA interference; CII: Type II collagen; CIA: Collagen-induced arthritis; DCs: Dendritic cells; Treg: Regulatory T cell.

\section{Acknowledgements}

This study is supported by the Canadian Institutes of Health Research (ClHR).

\section{Author details}

${ }^{1}$ Institute of Immunomodulation and Immunotherapy, Nanchang University Medical School, Nanchang, China. ${ }^{2}$ Departments of Surgery, Pathology, and Oncology, University of Western Ontario, London, Canada. ${ }^{3}$ Medistem Inc, San Diego, CA. ${ }^{4}$ Benitec Biopharma Limited, Sydney, NSW, Australia. ${ }^{5}$ Entest BioMedical, San Diego, CA. 'Division of Rheumatology, Department of Medicine, Toronto Western Hospital, University Health Network, Toronto, Canada. ${ }^{7}$ University Hospital C9-136, 339 Windermere Road, London, Ontario, N6A 5A5, Canada.

\section{Authors' contributions}

$R L, X i Z, I P, X u Z, H W, M S, D C$, LS carried out the experiments, WM, RI, PF, RN, DK participated in the project design, coordination the experiments, and helped to draft the manuscript. All authors read and approved the final manuscript.

\section{Competing interests}

The authors declare that they have no competing interests.

Received: 29 November 2011 Accepted: 31 January 2012

Published: 31 January 2012

\section{References}

1. Abeles AM, Pillinger MH: The role of the synovial fibroblast in rheumatoid arthritis: cartilage destruction and the regulation of matrix metalloproteinases. Bull NYU Hospital Joint Diseases 2006, 64:20-24.

2. Smeets TJ, Barg EC, Kraan MC, Smith MD, Breedveld FC, Tak PP: Analysis of the cell infiltrate and expression of proinflammatory cytokines and matrix metalloproteinases in arthroscopic synovial biopsies: comparison with synovial samples from patients with end stage, destructive rheumatoid arthritis. Ann Rheum Dis 2003, 62:635-638.

3. Smeets TJ, Kraan MC, Galjaard S, Youssef PP, Smith MD, Tak PP: Analysis of the cell infiltrate and expression of matrix metalloproteinases and granzyme B in paired synovial biopsy specimens from the cartilagepannus junction in patients with RA. Ann Rheum Dis 2001, 60:561-565

4. Cope AP, Schulze-Koops H, Aringer M: The central role of T cells in rheumatoid arthritis. Clin Exp Rheumatol 2007, 25:S4-S11.

5. Yamada H, Nakashima Y, Okazaki K, Mawatari T, Fukushi Jl, Kaibara N, Hori A, Iwamoto Y, Yoshikai Y: Th1 but not Th17 cells predominate in the joints of patients with rheumatoid arthritis. Ann Rheum Dis 2008, 67:1299-1304 
6. Yamada H, Nakashima Y, Okazaki K, Mawatari T, Fukushi J, Oyamada A Fujimura K, Iwamoto Y, Yoshikai Y: Preferential accumulation of activated Th1 cells not only in rheumatoid arthritis but also in osteoarthritis joints. J Rheumatol 2011, 38:1569-1575.

7. Choosing Medications for Rheumatoid Arthritis: Clinician's Guide Comparative Effectiveness Review Summary Guides for Clinicians. Rockville (MD) 2007, Ahrq].

8. Ichim TE, Harman RJ, Min WP, Minev B, Solano F, Rodriguez JP, Alexandrescu DT, De Necochea-Campion R, Hu X, Marleau AM, Riordan NH. Autologous stromal vascular fraction cells: a tool for facilitating tolerance in rheumatic disease. Cell Immunol 2010, 264:7-17.

9. Ichim TE, Zheng $X$, Suzuki M, Kubo N, Zhang X, Min LR, Beduhn ME, Riordan NH, Inman RD, Min WP: Antigen-specific therapy of rheumatoid arthritis. Expert Opin Biol Ther 2008, 8:191-199.

10. Sany J: Intravenous immunoglobulin therapy for rheumatic diseases. Curr Opin Rheumatol 1994, 6:305-310.

11. Bagchi D, Misner B, Bagchi M, Kothari SC, Downs BW, Fafard RD, Preuss HG: Effects of orally administered undenatured type II collagen against arthritic inflammatory diseases: a mechanistic exploration. Int J Clin Pharmacol Res 2002, 22:101-110.

12. Hauselmann HJ, Caravatti M, Seifert B, Wang K, Bruckner P, Stucki G, Michel BA: Can collagen type II sustain a methotrexate-induced therapeutic effect in patients with long-standing rheumatoid arthritis? A double-blind, randomized trial. Br J Rheumatol 1998, 37:1110-1117.

13. Kavanaugh A, Genovese M, Baughman J, Kivitz A, Bulpitt K, Olsen N, Weisman M, Matteson E, Furst D, van Vollenhoven $R$, et al: Allele and antigen-specific treatment of rheumatoid arthritis: a double blind, placebo controlled phase 1 trial. J Rheumato/ 2003, 30:449-454

14. Babatz J, Rollig C, Lobel B, Folprecht G, Haack M, Gunther H, Kohne CH, Ehninger G, Schmitz M, Bornhauser M: Induction of cellular immune responses against carcinoembryonic antigen in patients with metastatic tumors after vaccination with altered peptide ligand-loaded dendritic cells. Cancer Immunol Immunother 2006, 55:268-276.

15. Holtl L, Ramoner R, Zelle-Rieser C, Gander H, Putz T, Papesh C, Nussbaumer W, Falkensammer C, Bartsch G, Thurnher M: Allogeneic dendritic cell vaccination against metastatic renal cell carcinoma with or without cyclophosphamide. Cancer Immunol Immunother 2005, 54:663-670.

16. Chen M, Li YG, Zhang DZ, Wang ZY, Zeng WQ, Shi XF, Guo Y, Guo SH, Ren $\mathrm{H}$ : Therapeutic effect of autologous dendritic cell vaccine on patients with chronic hepatitis B: a clinical study. World J Gastroenterol 2005, 11:1806-1808.

17. Prasad SJ, Farrand KJ, Matthews SA, Chang JH, McHugh RS, Ronchese F: Dendritic cells loaded with stressed tumor cells elicit long-lasting protective tumor immunity in mice depleted of CD4+CD25+ regulatory T cells. J Immunol 2005, 174:90-98.

18. Bulloch MN, Elayan MM, Renfroe HR: Sipuleucel-T: a therapeutic cancer vaccine for the treatment of castration- or hormone-refractory prostate cancer. Expert Rev Clin Pharmacol 2011, 4:685-692.

19. Heng $Y$, Ma $Y$, Yin $H$, Duan $L$, Xiong $P$, Xu Y, Feng W, Fang $M$, Tan Z, Chen $Y$, et al: Adoptive transfer of FTY720-treated immature BMDCs significantly prolonged cardiac allograft survival. Transplant Int: Official J Eur Soc Organ Transplantation 2010, 23:1259-1270.

20. Mahnke K, Johnson TS, Ring S, Enk AH: Tolerogenic dendritic cells and regulatory T cells: a two-way relationship. J Dermatol Sci 2007, 46:159-167.

21. Popov I, Li M, Zheng X, San H, Zhang X, Ichim TE, Suzuki M, Feng B, Vladau $C$, Zhong $R$, et al: Preventing autoimmune arthritis using antigenspecific immature dendritic cells: a novel tolerogenic vaccine. Arthritis Res Therapy 2006, 8:R141.

22. Zheng $X$, Suzuki M, Ichim TE, Zhang $X$, Sun H, Zhu F, Shunnar A, Garcia B, Inman RD, Min W: Treatment of autoimmune arthritis using RNA interference-modulated dendritic cells. J Immunol 2010, 184:6457-6464.

23. Zheng $X$, Suzuki $M$, Zhang $X$, Ichim TE, Zhu F, Ling H, Shunnar $A$, Wang MH, Garcia B, Inman RD, Min WP: RNAi-mediated CD40-CD154 interruption promotes tolerance in autoimmune arthritis. Arthritis Res Therapy 2010, 12:R13.

24. Rosengren AT, Nyman TA, Lahesmaa R: Proteome profiling of interleukin12 treated human T helper cells. Proteomics 2005, 5:3137-3141.

25. O'Garra A, Hosken N, Macatonia S, Wenner CA, Murphy K: The role of macrophage- and dendritic cell-derived IL12 in Th1 phenotype development. Res Immunol 1995, 146:466-472.
26. Trinchieri G: Immunobiology of interleukin-12. Immunol Res 1998, 17:269-278.

27. Mauri C, Feldmann M, Williams RO: Down-regulation of Th1-mediated pathology in experimental arthritis by stimulation of the Th2 arm of the immune response. Arthritis Rheum 2003, 48:839-845.

28. Murphy CA, Langrish CL, Chen Y, Blumenschein W, McClanahan T, Kastelein RA, Sedgwick JD, Cua DJ: Divergent pro- and antiinflammatory roles for IL-23 and IL-12 in joint autoimmune inflammation. J Exp Med 2003, 198:1951-1957

29. Simpson PB, Mistry MS, Maki RA, Yang W, Schwarz DA, Johnson EB, Lio FM, Alleva DG: Cuttine edge: diabetes-associated quantitative trait locus, Idd4, is responsible for the IL-12p40 overexpression defect in nonobese diabetic (NOD) mice. J Immunol 2003, 171:3333-3337.

30. Trembleau S, Penna G, Gregori S, Giarratana N, Adorini L: IL-12 administration accelerates autoimmune diabetes in both wild-type and IFN-gamma-deficient nonobese diabetic mice, revealing pathogenic and protective effects of IL-12-induced IFN-gamma. J Immunol 2003 170:5491-5501.

31. Gran B, Zhang GX, Rostami A: Role of the IL-12/IL-23 system in the regulation of T-cell responses in central nervous system inflammatory demyelination. Crit Rev Immunol 2004, 24:111-128.

32. Brok HP, van Meurs M, Blezer E, Schantz A, Peritt D, Treacy G, Laman JD Bauer J: $t$ Hart BA: Prevention of experimental autoimmune encephalomyelitis in common marmosets using an anti-IL-12p40 monoclonal antibody. J Immunol 2002, 169:6554-6563.

33. Kimura H, Tzou SC, Rocchi R, Kimura M, Suzuki K, Parlow AF, Rose NR, Caturegli P: Interleukin (IL)-12-driven primary hypothyroidism: the contrasting roles of two Th1 cytokines (IL-12 and interferon-gamma). Endocrinol 2005, 146:3642-3651.

34. Chen K, Wei Y, Sharp GC, Braley-Mullen H: Induction of experimental autoimmune thyroiditis in IL-12-/- mice. J Immunol 2001, 167:1720-1727.

35. Hill JA, Ichim TE, Kusznieruk KP, Li M, Huang X, Yan X, Zhong R, Cairns E, Bell DA, Min WP: Immune modulation by silencing IL-12 production in dendritic cells using small interfering RNA. J Immunol 2003, 171:691-696.

36. Elbashir SM, Harborth J, Weber K, Tuschl T: Analysis of gene function in somatic mammalian cells using small interfering RNAs. Methods 2002, 26:199-213.

37. Zhu X, Imamura M, Tanaka J, Han CW, Hashino S, Imai K, Asano M, Nakane A, Minagawa T, Kobayashi M, et al: Effects of 15-deoxyspergualin in vitro and in vivo on cytokine gene expression. Transplantation 1994, 58:1104-1109.

38. Schurgers E, Billiau A, Matthys P: Collagen-Induced Arthritis as an Animal Model for Rheumatoid Arthritis: Focus on Interferon-gamma. Journal of interferon \& cytokine research: the official journal of the International Society for Interferon and Cytokine Research 2011, 31.917-926.

39. Steinbrink K, Wolfl M, Jonuleit $H$, Knop J, Enk AH: Induction of tolerance by IL-10-treated dendritic cells. J Immunol 1997, 159:4772-4780.

40. Butler DM, Malfait AM, Maini RN, Brennan FM, Feldmann M: Anti-IL-12 and anti-TNF antibodies synergistically suppress the progression of murine collagen-induced arthritis. Eur J Immunol 1999, 29:2205-2212.

41. Litinskiy MB, Nardelli B, Hilbert DM, He B, Schaffer A, Casali P, Cerutti A: DCs induce CD40-independent immunoglobulin class switching through BLyS and APRIL. Nat Immunol 2002, 3:822-829

42. Kim SH, Kim S, Evans $\mathrm{CH}$, Ghivizzani SC, Oligino T, Robbins PD. Effective treatment of established murine collagen-induced arthritis by systemic administration of dendritic cells genetically modified to express IL-4. J Immunol 2001, 166:3499-3505.

43. van den Berg WB: Animal models of arthritis. What have we learned? J Rheumatol Supp/ 2005, 72:7-9.

44. Pearson TC, Trambley J, Odom K, Anderson DC, Cowan S, Bray R, Lin A, Hollenbaugh D, Aruffo A, Siadak AW, et al: Anti-CD40 therapy extends renal allograft survival in rhesus macaques. Transplantation 2002, 74:933-940.

45. Bonham CA, Peng L, Liang X, Chen Z, Wang L, Ma L, Hackstein H, Robbins PD, Thomson AW, Fung JJ, et al: Marked prolongation of cardiac allograft survival by dendritic cells genetically engineered with NFkappa B oligodeoxyribonucleotide decoys and adenoviral vectors encoding CTLA4-lg. J Immunol 2002, 169:3382-3391.

46. Li S, Thanikachalam M, Pang M, Kawaharada N, Aitouche A, Pham SM: A clinically relevant CTLA4-Ig-based regimen induces chimerism and tolerance to heart grafts. Ann Thorac Surg 2001, 72:1306-1310. 
47. Giannoukakis N, Bonham CA, Qian S, Chen Z, Peng L, Harnaha J, Li W, Thomson AW, Fung JJ, Robbins PD, Lu L: Prolongation of cardiac allograft survival using dendritic cells treated with NF-kB decoy oligodeoxyribonucleotides. Mol Ther 2000, 1:430-437.

48. Bertrand J, Pottier M, Vekris A, Opolon P, Maksimenko A, Malvy C: Comparison of antisense oligonucleotides and siRNAs in cell culture and in vivo. Biochem Biophys Res Commun 2002, 296:1000.

49. Celotto AM, Graveley BR: Exon-specific RNAi: a tool for dissecting the functional relevance of alternative splicing. RNA 2002, 8:718-724.

50. Grishok A, Tabara H, Mello CC: Genetic requirements for inheritance of RNAi in C. elegans. Science 2000, 287:2494-2497.

51. Brummelkamp TR, Bernards R, Agami R: A system for stable expression of short interfering RNAs in mammalian cells. Science 2002, 296:550-553.

52. Paul CP, Good PD, Winer I, Engelke DR: Effective expression of small interfering RNA in human cells. Nat Biotechnol 2002, 20:505-508.

53. Devroe E, Silver PA: Retrovirus-delivered siRNA. BMC Biotechnol 2002, 2:15.

54. Pardridge WM: Intravenous, non-viral RNAi gene therapy of brain cancer. Expert Opin Biol Ther 2004, 4:1103-1113.

55. Yang D, Buchholz F, Huang Z, Goga A, Chen CY, Brodsky FM, Bishop JM: Short RNA duplexes produced by hydrolysis with Escherichia coli RNase III mediate effective RNA interference in mammalian cells. Proc Natl Acad Sci USA 2002, 99:9942-9947.

56. DiGiusto DL, Krishnan A, Li L, Li H, Li S, Rao A, Mi S, Yam P, Stinson S, Kalos $M$, et al: RNA-based gene therapy for HIV with lentiviral vectormodified CD34(+) cells in patients undergoing transplantation for AIDSrelated lymphoma. Sci Translational Med 2010, 2:36ra43.

57. Laderach D, Compagno D, Danos O, Vainchenker W, Galy A: RNA interference shows critical requirement for NF-kappa B p50 in the production of IL-12 by human dendritic cells. J Immunol 2003, 171:1750-1757.

58. Wong AW, Brickey WJ, Taxman DJ, van Deventer HW, Reed W, Gao JX, Zheng P, Liu Y, Li P, Blum JS, et al: CIITA-regulated plexin-A1 affects Tcell-dendritic cell interactions. Nat Immunol 2003, 4:891-898.

59. Li M, Zhang X, Zheng X, Lian D, Zhang ZX, Ge W, Yang J, Vladau C, Suzuki $M$, Chen $D$, et al: Immune modulation and tolerance induction by RelB-silenced dendritic cells through RNA interference. J Immunol 2007, 178:5480-5487.

60. Li M, Qian H, Ichim TE, Ge WW, Popov IA, Rycerz K, Neu J, White D, Zhong R, Min WP: Induction of RNA interference in dendritic cells. Immunol Res 2004, 30:215-230.

doi:10.1186/1479-5876-10-19

Cite this article as: Li et al:: Gene silencing of IL-12 in dendritic cells inhibits autoimmune arthritis. Journal of Translational Medicine 2012 10:19.

\section{Submit your next manuscript to BioMed Central and take full advantage of:}

- Convenient online submission

- Thorough peer review

- No space constraints or color figure charges

- Immediate publication on acceptance

- Inclusion in PubMed, CAS, Scopus and Google Scholar

- Research which is freely available for redistribution

Submit your manuscript at www.biomedcentral.com/submit
C Biomed Central 